and the power to solve, in its own ways, the problem of population. If there be the possibility of enlargement of the means of subsistence, of renewed expansion, then this should be completely explored; but if such expansion is impossible, then the aim of society must be to ascertain the limits in which an optimum population can enjoy the maximum of liberty. In both tasks the method must be that of the social experiment. Though Prof. Hjort mainly restricts himself to a discussion of the method of research and experiment in its application to social problems, he does not avoid the conclusion that an economically re-united Europe would afford conditions for a new emancipation, for a recovery of the freedom that the War destroyed. For, he holds, this would bring peace, and peace amongst men is not a natural state of things; it does not make itself, but must be made.

Representation of Science on Government Commissions

As announced last week in this column, the Postmaster-General is about to set up a committee to consider the development of television, and to advise on the conditions under which any public television service should be provided. It is understood that the personnel of the committee is to consist of representatives of the Post Office, the British Broadcasting Corporation, and the Department of Scientific and Industrial Research. A committee so constituted, presuming that some of the members have practical knowledge of the problems involved in television, would command that measure of public confidence which is necessary if its deliberations are to find general acceptance; and it would be an advance on many Commissions and committees appointed by the Government in this respect. For reasons which it is difficult to understand, there has been a lamentable tendency on the part of Ministers to pass over scientific men in setting up Royal Commissions, committees, and departmental committees, even when matters in which scientific and technical issues are involved.

Ir is to be hoped that the constitution of the television committee is a sign that the Governmental mind is being quickened in this respect. Time and again, we have urged that no body set up to consider any subject with scientific or technical ramifications can be adequate or complete unless it includes scientific workers or technicians in its personnel. The Parliamentary Science Committee-a body representing the British Science Guild, the Association of Scientific Workers, and a number of learned societies-has also taken up the matter, urging the Prime Minister to insist on his colleagues observing this principle. Some fifteen months ago the Postmaster-General appointed a Post Office Advisory Committee. If this body is to be of real service it will, presumably, have to advise on technical matters such as telephony and telegraphy. Yet no one with scientific or technical qualifications was appointed amongst a numerous membership. There is now a vacancy occasioned by the death of the Hon. Mary Pickford, thus affording an opportunity of rectifying this state of affairs.

\section{Scientific Method and Politics}

THe first instalment of a tabular analysis of various social and economic systems, in the form of answers to a questionnaire prepared by the Engineers' Study Group on Economics (NATURE, 132, 635, Oct. 21, 1933) is to appear in the forthcoming issue of Progress, the organ of the Association of Scientific Workers. The Study Group, apart from research investigations, arranges for discussions on questions of the moment, at which those engaged in any branch of scientific work are welcomed. On May $16 \mathrm{Mr}$. Harold Macmillan, M.P., will address the Group on "Reconstruction". The meeting will be at 7.45 for 8 p.m. at Denison Hall, 296 Vauxhall Bridge Road, Victoria, and Sir Richard Gregory will take the chair. Tickets may be obtained from the honorary secretary of the Group, Col. P. Johnson, Gunnersbury House, Hounslow, Middlesex.

THE interest which scientific workers are beginning to show in social and economic questions is not restricted to Great Britain. In France there are several active groups. The Centre Polytechnicien d'Etudes Economiques (12 rue de Poitiers, Paris; president, M. Gerard Bardet) consists mainly of former students of the Ecole Polytechnique, one of the best-known engineering colleges in France, and is now in its third year of existence. Another, the Centre d'Etudes Economiques de l'Alimentation (39 boulevard de Sebastopol, Paris; president, M. André Roussel) was formed by the fusion of three pre-existing groups drawn from the Ecole Polytechnique, Ecole des Centraux and the Institut Agronomique. Both organisations publish bulletins regularly, giving the results of their studies on economics and production and distribution of foodstuffs.

\section{Unemployment and Poverty in India}

IN a recent article in the Karachi Daily Gazette, Capt. Petavel, formerly lecturer on the poverty problem at the University of Calcutta, strongly advocates the formation of co-operative colonies as a solution of the problems of unemployment and poverty in India. $\mathrm{He}$ suggests that the colonies should be open not only to those who have merely their labour to offer, but also to those who would contribute capital, land or equipment. All would be co-operators in their way, and would have a share of the products. The workers' remuneration would be mainly in kind, but part might be in money. This would enable the more ambitious to save, and in time to launch out on any small undertaking they might fancy. If they failed, they could return to the colony, which would.thus provide opportunity with security. As the colonies developed, they could adopt a system of 'exchange tickets' redeemable in the produce of the colony. Thus it is claimed purchasing. power would always be commensurate with productive power. People could always get work in the colony, because they would get a ticket to take away what they had produced. To reinforce his argument, the author refers to the Swiss Labour Colony at Witzwil and that at Llano in Louisiana. 